\title{
Crack Detection Method for Drain by Using Directional Smoothing
}

\author{
Toshiyuki Hatada Non-member (Gifu University) \\ Fumihiko Saitoh Member (Gifu University)
}

Keywords : crack detection, directional smoothing, drain

This paper proposes an improved method for the method to detect a crack of drain. The conventional method can detect candidate pixels for a crack from an image of inner side of drain. This new method is aiming the directionality of cracks. But at the part of a crack whose direction is changed frequently, as shown in Fig.1, the crack detection tends to fail. The goals of the proposed method are resolving this problem by improving the continuity of a crack and making the detecting rate improved.

Failures are often caused by noise pixels on cracks. The candidate pixels for a crack are assumed to be detected by improving its continuity. In the case of noise structures cross a crack, its continuity becomes inferior. The proposed method removes noise pixels by using directional smoothing process. Fig.2. shows the basic concept of the directional smoothing. As the smoothing to the horizontal line, if taking the average value of the upper and the lower pixels as the output by the smoothing, the line structure will be broken (Fig.2(a)). But if the left and right pixels are selected, the structure is preserved. Therefore, to reduce noise pixels for cracks, the directional smoothing in which its direction is controlled properly is assumed to be efficient.

As shown in Fig.3, the proposed method repeats two processes:

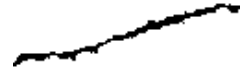

(a)Ideal
(b)Actual(Lacked)
Fig. 1. Example of lacking

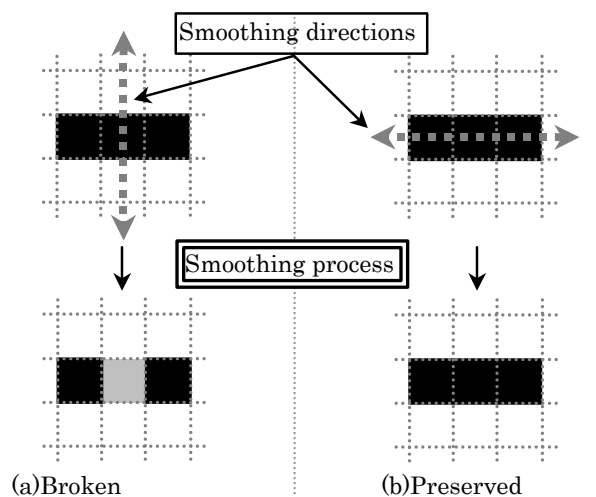

Fig. 2. Relationship of smoothing and line directions one is the crack detection process and the other is the noise-reducing process. The output image by the crack detection process indicates candidate pixels for cracks. Most of these candidate pixels indicate a part of a crack correctly, and the information for the direction of the crack is also obtained. By using this information, the direction for smoothing can be determined, because the direction of the lacked crack is similar to adjacent cracks.

The input image is renewed through the directional smoothing process. A renewed image has less noise pixels than original one. Consequently, a superior result is generated as the output from the crack detection process.

Fig.4 shows the experimental results. Compared to the conventional resultant images, the ones by the proposed method are considered to be improved, and efficiency of the proposed method is useful for detecting the crack pixels.

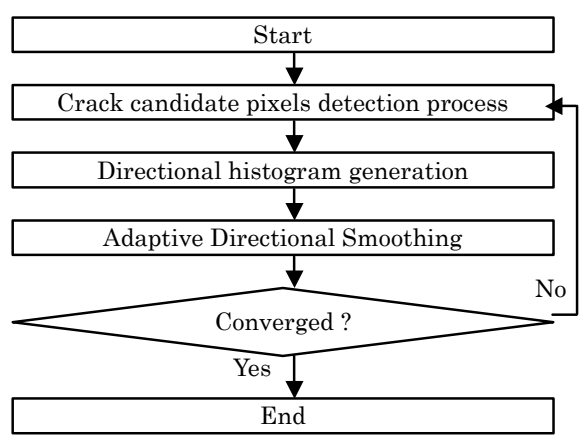

Fig. 3. Flow-chart of proposed method

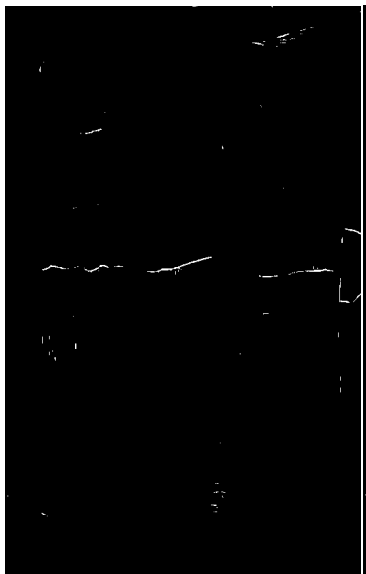

(a) Conventional method.

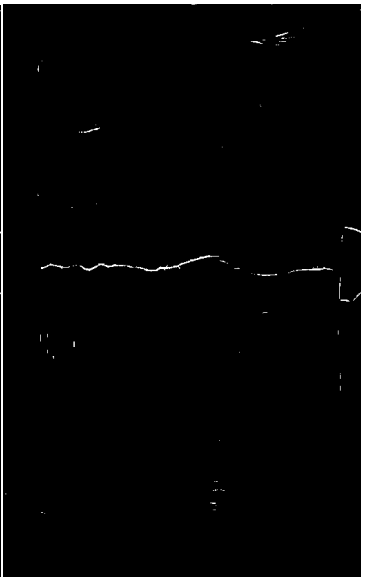

(b) Proposed method.
Fig. 4. Comparison of resultant image (Image2) 


\title{
論 文
}

\section{方向性平滑化による下水道内面ひび割れ候補画素検出}

\author{
非会員 幡田 敏行* 正 員 斉藤 文彦* \\ Crack Detection Method for Drain by Using Directional Smoothing
}

Toshiyuki Hatada*, Non-member, Fumihiko Saitoh*, Member

\begin{abstract}
This paper proposes an improved method to detect a crack of drain. The conventional method tends to fail to detect a crack where its direction is changed. The proposed method solves this problem by smoothing structures of crack. A crack has a global direction in large scaled background structures. Therefore the smoothing process to the direction of a crack is supposed to be useful for reducing noise structures without the influence to crack structures. It makes the continuity of cracks improved, and helps the crack detection method to obtain superior results. The two processes are repeated in the proposed method: one is the crack detection process and the other is the noise-reducing process. The experimental results show that the proposed method is useful for improving the detection rate of the crack pixels in comparison with the conventional method.
\end{abstract}

キーワード : ひび割れ検出, 方向性平滑化, 下水道

Keywords : crack detection, directional smoothing, drain

\section{1. はじめに}

コンクリートやモルタルで形成された建造物は，長期利 用による劣化から，破損が生じる。ひび割れは，そうした 破損の中でも代表的なものであり，下水道検査においても， 重点を置かれている。目視によるひび割れを分析し診断す るシステムは提案されているが(1)(2), 目視の検査では, 検査 者の熟練度による診断精度のばらつきが問題となる。トン ネルのひび割れ検査では，レーザーを用いた大型のセンシ ングシステムによる, 自動化も報告されているが(3), 本論文 で対象とする下水道では，人間が直接入ることができない 太さの区間もあることから利用ができない。下水道内面の ひび割れ検出の自動化は未だ実現がされておらず，本研究 はその実現を最終目標としている。

下水道内面検査では, 図 1 に示すような静止画像を目視 によって検査を行っている(4)。これらの画像は, 図 2 に示す ビデオカメラを先端に装備した走行型ロボットを用いて撮 影された動画像から生成される。しかし，下水道 1 区間よ り得られる画像が 2000 枚程度と膨大であり, 目視検査では 長時間を要するため, 自動化システムが求められている。 下水道内面より，ひび割れの連続性に着目した，ひび割れ 候補画素の検出手法が提案されているが(5)，ひび割れの方向 が不連続に変化する部位では欠落が生じる傾向がある。

\footnotetext{
* 岐阜大学工学部応用情報学科

于501-1193 岐阜県岐阜市柳戸 1-1

Department of Information Science, Faculty of

Engineering, Gifu University

1-1 yanaido, Gifu City, Gifu 501-1193
}

提案手法では，方向適応型の平滑化を行うことで，ひび 割れの連続性の妨げとなるノイズ画素を低減し, 従来手法 に対して検出精度を向上させることを図る。方向適応型の 平滑化によるノイズ低減手法は, 構造物間のコントラスト が高く, 空間周波数が比較的低い画像に対して用いられて いるが(6), 高コントラストな画像に向く手法であり, コント ラストが低い部分を多く含む下水道内面画像には向かな い。提案手法では，広い範囲で方向性に関する分布を持つ 構造に対して有効に作用する平滑化処理を行い, ひび割れ 候補画素の検出率を高めることを目標とする。

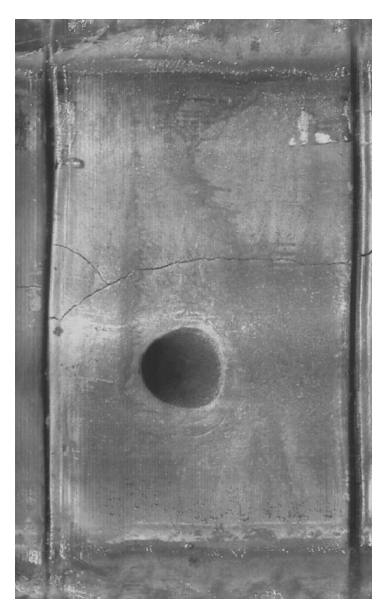

(a) Image 1.

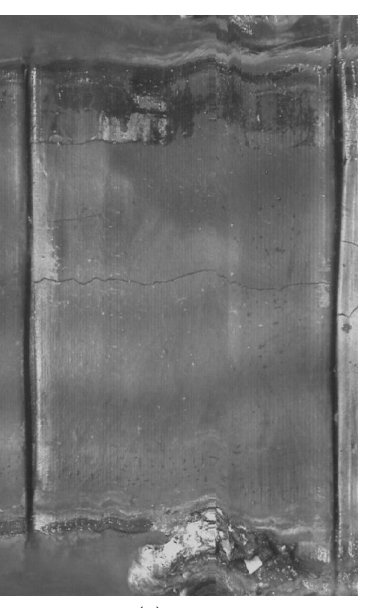

(b) Image2.
図 1 下水道内面画像

Fig. 1. Images of drains. 


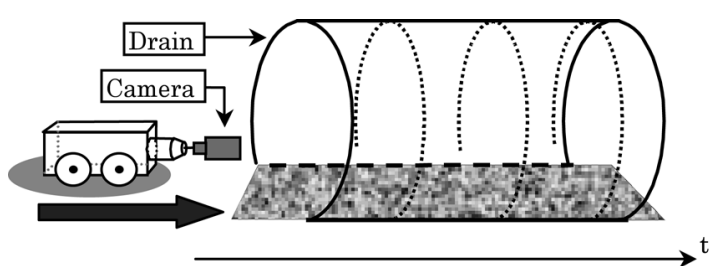

図 2 下水道内面画像の撮影

Fig. 2. Image recording in a drain.

\section{2. ひび割れ候補画素検出手法}

下水道内面画像における, ひび割れの特徵と, 従来のひ び割れ候補画素検出手法(5)について説明する。

〈2·1〉ひび割れの背景構造物に対する特徵図 1 か らも確認できるように，ひび割れは，複雑な形状を持つが， 広い範囲で方向性を持つ細い線状の構造物と見なせる。一 方で，ひび割れ検出に関してノイズとなる背景構造物で, 方向性を持ち，かつ線状であるものは少ない。従って，ひ び割れ検出には，方向性を考慮する手法が有効であると考 えられる。

〈2·2〉ひび割れ候補画素検出手法従来手法では， ひび割れの方向性に着目をし，入力画像に線検出フィルタ を適用し, その出力画像へ 2 值化処理を施す。用いるフィ ルタは, 代表的な Sobel や Prewitt フィルタ(7)(8)のようなサ イズが $3 \times 3$ 画素に固定されたものではなく, 対象の構造物 に応じて, 画素ごとに, 方向とサイズを適応的に変化させ る方向サイズ可変フィルタ (Variable-sized Directional Filter：VSDF)を用いる。VSDF は，方向性を持つ線構造物 に特に高い值を出力することから，ひび割れ検出に適して いるフィルタといえる。このフィルタを適用して得られる 出力濃淡画像と, フィルタが作用した方向成分を調べるこ とで，背景構造物とひび割れを識別する。

$\langle 2 \cdot 3\rangle$ 従来手法の問題点前節で説明した手法で は，図 3(a)に示すような連続的なひび割れに対しては適切 な処理が可能である。しかし，ひび割れ上にノイズが発生 している場合や，図 3(b)に示すような，方向変化が不連続 な部位ではVSDF が適切に作用せず，正しくひび割れ候補 画素が検出されない傾向がある。これは，不連続な方向変 化や，ノイズ画素が多い部位では，VSDF における方向性 の有無が適切に判断されないことにより生じる問題であ る。

\section{3. ひび割れ候補画素検出の改善手法}

〈3.1〉提案手法の基本的な考え方 ひび割れは全体 として方向性をもち，1つのひび割れでは，その広局所的な 方向はほぼ同一である。例えば，図 4(a)の理想的な検出結 果に対し, 同図(b)に示す欠落部位が生じている場合でも, 同図(c)に示すように，久落部位の方向は周辺のひび割れの 方向から推定できると考えられる。この点に着目をし，提 案手法では，ひび割れ候補画素検出処理により，ひび割れ

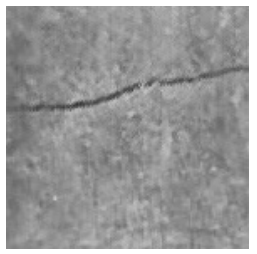

(a)Continuous

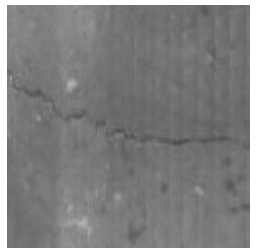

(b)Discontinuous
図 3 ひび割れの連続部位と不連続部位例

Fig. 3. Continuous and discontinuous parts of cracks.

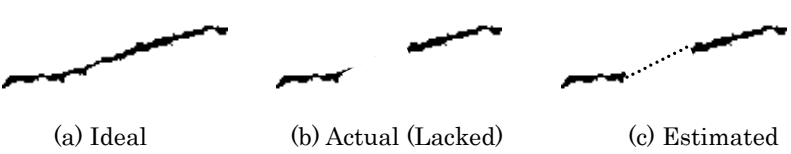

図4 久落を生じたひび割れの推定例

Fig. 4. Example of estimated crack.

候補として得た画素の位置情報を用いて, その画素周辺の 位置について, 入力画像に方向性を持たせた平滑化処理を 行う。平滑化処理は，ノイズの低減効果があると同時に, 不連続に方向を変化させる部位については, 不連続さを生 じる原因となった中間に位置する画素濃度值を, ひび割れ の濃度值に近づけさせることができる。平滑化処理後に得 られる画像は, 処理前よりも連続性が向上し, その画像を 新たに入力画像としたひび割れ候補画素検出では, 初期入 力画像に対して, 精度がより向上することが期待される。 提案手法では，この考えに基づき，平滑化処理とひび割れ 候補画素検出処理を反復的に用いることにより, 最終的な 検出精度を高める。

ここで，方向性を持たせた平滑化とは，例えば，出力を 注目画素の左右 2 画素の平均值とするものである。図 5 は, 水平方向一走る線構造物に対して, 2 つの方向について平滑 化を行った結果の違いを表している。図 5(a)のように, 構 造物に対して垂直な方向への平滑化は, 構造物の濃度值を 大きく変化させ，構造を破壊している。一方，同図(b)のよ うに, 構造物が走る方向に平行な方向への平滑化は, 画素 濃度值はほとんど変化せず, 構造を維持している。従って, ひび割れ上にノイズ画素が存在している場合, ひび割れに 平行な方向へ平滑化処理を行うことで, ノイズの低減が期 待できる。

平滑化の方向は, ひび割れ候補画素検出処理によって得 られた, ひび割れ候補画素の方向と, 同一方向を持つ画素 数によって決定される。ここで，ひび割れ候補画素には， 真のひび割れと誤識別されたノイズ画素も含まれる。〈2・ 1〉節で述べたように, ひび割れは, 背景構造物よりも広い 範囲で方向性を持つ。このため, ノイズ画素周辺で平滑化 を行った場合は，方向が同じとなる画素が少ないため，， イズに対する平滑化の働きは，ひび割れに対するものより も弱くなる。

以上に述べた平滑化処理を施して得られた画像を新しい 


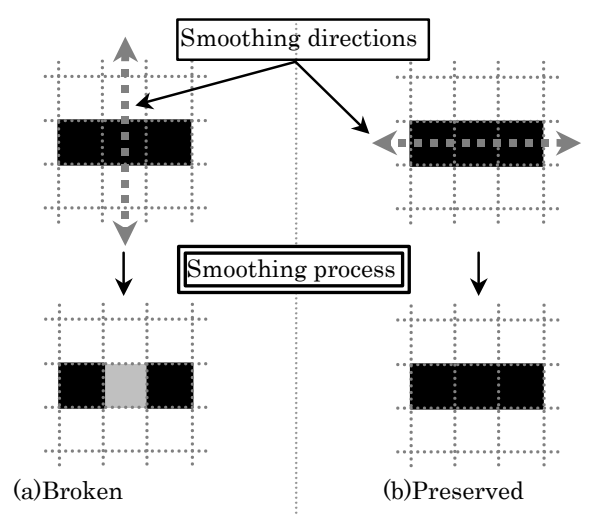

図 5 平滑化の方向と結果の関係

Fig. 5. Relationship of smoothing and line directions.

入力画像とし, 改めてひび割れ候補画素検出を行うことで, 初回よりも良好な検出結果を得ることが期待できる。提案 手法では, 図 6 に示すように, ひび割れ検出とノイズ低減 処理を反復させることにより，最終的な検出精度を向上さ せる。以下では，それぞれの処理について具体的に述べる。 なお, この反復処理で, 第 $n$ 回目の入力画像を $I_{n}$, 出力画 像を $O_{n}$ と表記する。

〈3·2〉方向性平滑化平滑化は, 次式で表される計算 により行う。

$$
S(i, j)=\sum_{d=1}^{4} w_{d} \cdot A_{d}(i, j)
$$

但し

$$
\sum_{d=1}^{4} w_{d}=1
$$

とする。ここで, $A_{d}(i, j)$ は座標 $(i, j)$ における入力画像 $I_{n}$ の 8 近傍領域における各方向に対する平均濃度值であり, 次式 によって計算される。

$$
\begin{aligned}
& A_{1}(i, j)=0.5 \cdot\left(I_{n}(i-1, j-1)+I_{n}(i+1, j+1)\right) \\
& A_{2}(i, j)=0.5 \cdot\left(I_{n}(i-1, j)+I_{n}(i+1, j)\right) \\
& A_{3}(i, j)=0.5 \cdot\left(I_{n}(i-1, j+1)+I_{n}(i+1, j-1)\right) \\
& A_{4}(i, j)=0.5 \cdot\left(I_{n}(i, j-1)+I_{n}(i, j+1)\right)
\end{aligned}
$$

$w_{d}$ は，それぞれの方向に対する重み係数であり，図 7 に示 す方向に対応する。 $w_{d}$ がひび割れ部位に対して適切に決定 されるよう制御することで，欠落部位上にあるノイズを低 減させる。ひび割れ候補として検出されなかった画素が, 正しくはひび割れである場合，その方向は距離が近いひび 割れの方向と類似していると推定される。しかし，図 8 に 示すようなひび割れが交差する部分などでは，その方向が 一意には定まらない。この場合，ある一方向だけの平滑化 処理を行うことは適切ではなく, $3 \pi / 4, \pi / 4$ の 2 方向に対 応させ, 式(3)での $A_{1}(i, j)$ と $A_{3}(i, j)$ の平均值を出力とする ことが適切であると考えられる。これは, 式(1)中での重み 係数 $w_{d}$ を $w_{1}=0.5, w_{2}=0, w_{3}=0.5, w_{4}=0$ と設定したこ とに相当する。方向係数の決定については次節にて説明す る。

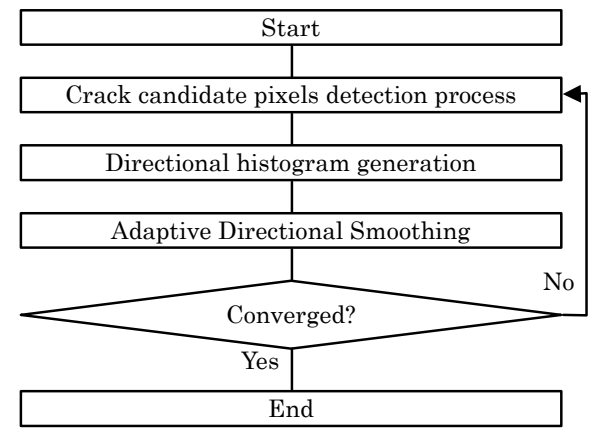

図 6 提案手法の流れ

Fig. 6. Flow-chart of the proposed method.

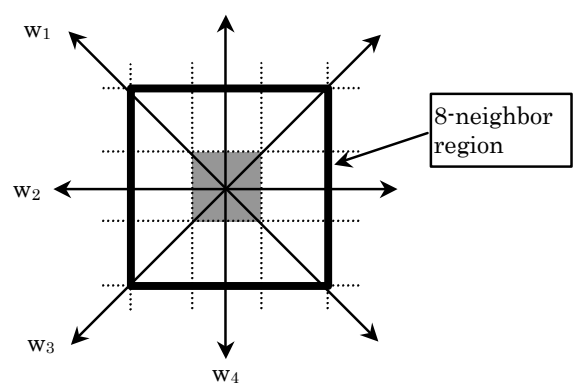

図 7 方向と係数の関係

Fig. 7. Relation between directions and coefficents.

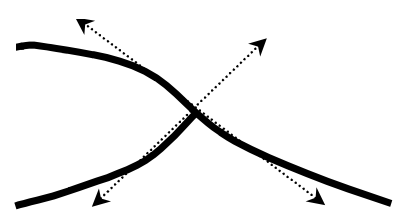

図 8 部分的に 2 方向を持つ構造物

Fig. 8. Example of an object with two local directions.

〈3.3〉方向係数の決定 図 4(c)に示したような，欠 落部位の推定は，ひび割れが短い範囲で分布の方向を一定 に保っている性質と, 目視によって 2 点間を結ぶ作業 ${ }^{(9)}$ に基 づく。そこで, 一度検出された候補画素について, その画 素が持つ方向 $\theta$ より，方向係数を決定する。この場合，あ る画素に対して, 周辺の候補画素における, 複数の方向成 分を考慮する必要がある。そこで, 重み係数を決定する際 には, ある候補画素の座標 $(i, j)$ を中心して得られた局所 的な方向の情報を， $(i, j)$ を中心とした周辺領域に対して, 方向ヒストグラムとして累積する。その際の領域範囲を局 所的方向 $\theta$ と広局所的方向 $\varphi$ を基に適応的に変化させるこ とで，最終的な方向係数を決定する。ここでの広局所的方 向とは, 図 $9(\mathrm{a})$ に示すような構造物全体の方向 $\varphi$ であり, 局所的方向は, 同図(b)に示すような座標ごとの方向 $\theta$ であ る。このように，周辺領域の方向情報を集めることで，広 い範囲で方向性を持つひび割れの特徵が表される。

以下に，広局所的方向 $\varphi$ と局所的方向 $\theta$ の求め方につい て述べる。また，ひび割れは線形状であり，伸びている方 
向が重要であることから, 後の処理を簡略化するために, 一度画像 $O_{n}$ を細線化した画像 $T_{n}$ より方向を求める。

$\langle 3 \cdot 3 \cdot 1\rangle$ 広局所的方向 1 つの構造物は, ラベリン グ処理で同一ラベルとなった領域とし, 構造物ごとの広局 所的方向 $\varphi$ は, 慣性主軸 ${ }^{(10)}$ 方向とする。まず画像 $T_{n}$ に対し て 8 近傍領域を同一構造物とするラベリング処理によって ラベル画像 $L_{n}$ を生成する。次にラベル領域ごとに次式によ って慣性主軸を広局所的方向 $\varphi$ として計算する。

$$
\varphi=\frac{1}{2} \tan ^{-1}\left(\frac{2 M_{11}}{M_{20}-M_{02}}\right)
$$

但し,

$$
M_{p q}=\sum_{i} \sum_{j}\left(i-g_{x}\right)^{p}\left(j-g_{y}\right)^{q} f(i, j)
$$

である。座標 $\left(g_{x}, g_{y}\right)$ は，構造物の重心座標を表す。

$\langle 3 \cdot 3 \cdot 2\rangle$ 局所的方向 座標ごとの局所的方向 $\theta$ は, 図 10 に示す 4 方向分のフィルタを用いて求める。これらの フィルタは, 角度 $3 \pi / 4,0, \pi / 4, \pi / 2$ に対応し, 出力が最大值 をとったフィルタの角度を $\theta(i, j)$ 一記録する。但し, 最大 值を持つフィルタが複数になった場合は, $\theta(i, j)$ は不定と して扱う。

〈3·3·3〉方向ヒストグラム生成＼cjkstart次にひび割れ候補 画素から得られる 4 方向の頻度をヒストグラムに累積する。 各候補画素より得た $\theta(i, j)$ を, 次式で決定される正方領域 $(x-d x, y-d y)-(x+d x, y+d y)$ 内の座標に対応するヒスト グラムへ累積する。

$$
\begin{aligned}
& d x=N(l) \cdot\lfloor|\cos (\varphi(L(i, j))-\theta(i, j))+0.5|\rfloor \\
& d y=N(l) \cdot\lfloor|\sin (\varphi(L(i, j))-\theta(i, j))+0.5|\rfloor
\end{aligned}
$$

$N(l)$ は, ラベル值 $l$ の画素数である。画素が多い構造物ほ ど, 離れた領域の構造物と関係すると考えられるため, ヒ ストグラムの累積対象領域のサイズを $N(l)$ に比例させてい る。ラベル值 $l$ のひび割れは全体として $\varphi(l)$ の方向へ伸びて いることから， $\varphi(l)$ と差の小さい方向 $\theta$ を持つ画素は，真 のひび割れ画素の可能性が高く, 差が大きい画素はノイズ 画素の可能性が高いと考えられる。そこで，ひび割れの可 能性が高い画素の影響を強く反映させるために, 領域範囲 の設定に角度差を用いる。

ヒストグラムへ累積する值には, 得られた方向への距離 に反比例させた重みをつける。座標 $(u, v) \in(-d x \leq u \leq d x,-d y \leq v \leq d y)$ は, 中心座標 $(i, j)$ から七 ストグラムへ累積する範囲上での座標とし， ヒストグラム での方向パラメータを $d=\theta(i, j)$ とすると, 累積する值は次 式で計算される。

$$
h_{d}(u, v) \leftarrow h_{d}(u, v)+\frac{1.0}{\sqrt{(i-u)^{2}+(j-v)^{2}}+1}
$$

〈3·3·4〉平滑化重み係数の決定 得られたヒストグ ラム $h(i, j) よ り$, 平滑化の重多係数 $w_{d}$ は次式によって決定 される。

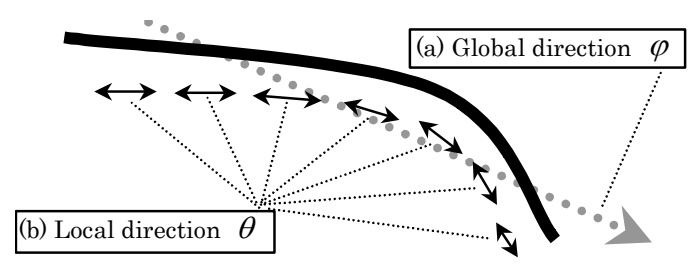

図 9 局所的方向と広局所的方向

Fig. 9. Local and global direction of object.

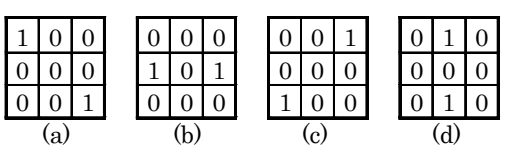

図 10 方向検出フィルタ

Fig. 10. Directional detection filters.

$$
w_{d}(i, j)=\frac{h_{d}(i, j)}{\sum_{d=1}^{4} h_{d}(i, j)}
$$

決定された $w_{d}$ によって式(1)を全ての座標について計算し, 出力画像 $O_{n}$ を得る。但し, ヒストグラムの累積合計值がゼ ロの場合は, 平滑化処理を施さず, 入力画像と同じ濃度值 とする。

〈3-4〉入力画像の更新と収束判定 反復処理過程を 通して, 平滑化処理が充分施され, 処理が収束した場合に 反復を停止する。なお，方向性のある平滑化を複数回繰り 返すことにより，適用領域がランダムなパターンであって も, 筋状パターンがノイズとして発生する場合がある。平 滑化が有効に働くと, その方向に対して垂直方向のパター ンが減少するため, 式(1)の平滑化の対象である $3 \times 3$ 画素の 領域での濃度分散 $V$ は減少する。一方, ノイズが新たに発 生すると, $V$ は増加に転ずる。従って, 平滑化画像 $S_{n}$ の座 標 $(i, j)$ における周辺の分散值 $V_{n}(i, j)$ が, 一段階前の平滑化 画像 $S_{n-1}$ での分散值 $V_{n-1}(i, j)$ と比較し, 值が小さくなり続け ている間は, $I_{n}(i, j)$ を $S_{n}(i, j)$ とし, この条件を満たさない 座標では, 值を変化させず, 入力画像 $I_{n}(i, j)$ と同じとする ことで, $I_{n+1}(i, j)$ を求める。これは次式によって表される。

$$
I_{n+1}(i, j)= \begin{cases}S_{n}(i, j) & \left(\text { if } V_{n}(i, j) \leq V_{n-1}(i, j)\right) \\ I_{n}(i, j) & (\text { otherwise })\end{cases}
$$

画像 $I_{n+1}$ と画像 $I_{n}$ を比較し, 更新された画素がなくなった ら，平滑化処理が収束したとし，処理を終了する。

\section{4. 実験結果}

以上に述べた手法を下水道内面画像に適用し, 従来手法 を利用した場合と提案手法による結果を, 出力画像と定量 的評価を用いて比較した。

〈4·1〉実験条件 実験で用いた対象画像は, 図 1 に 示す, それぞれサイズが $800(\mathrm{~W}) \times 1280(\mathrm{H})$, 濃淡レベル 8 ビットの画像 Image1, Image2 である。処理は PC (OS: Linux, CPU: Pentium4-3.2GHz) にて行った。 


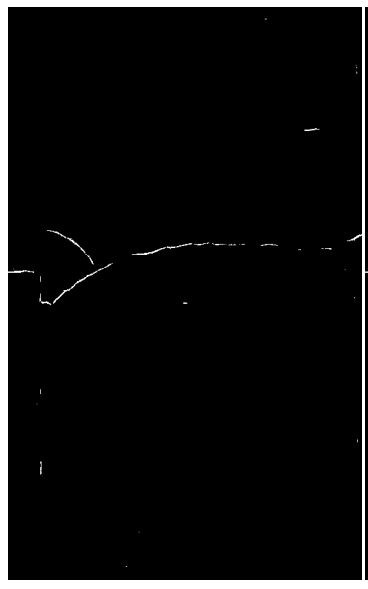

(a) Conventional method. 図 11 出力画像比較(Image1)

Fig. 11. Comparison of resultant images.(Image1)

〈4-2〉結果画像比較 結果画像の比較を図 11 , 図 12 に示す。Image1については, 従来手法では, 画像中央右側 部分において，部分ごとに検出されていたひび割れが連結 し，連続性が向上したことが確認できる。Image2 について は，細かな部分ごとの連結に加え，大きく欠落していた部 分の検出状態も改善されていることが確認できる。双方の 画像ともノイズ画素は，やや増加しているが，新たにサイ ズの大きい誤った構造物は検出されなかった。これらのノ イズ画素は, 従来からのノイズ画素の付近に生じている。 これは，ひび割れと同様に，各段階で検出された誤識別画 素と同じ方向性を持つ，別のノイズ画素が強調されたもの と考えられる。しかし，ノイズ画素は，ひび割れほどの連 続性を持たないことから，視覚的には目立たない結果とな っている。

〈4·3〉定量評価次に，従来手法で用いられた，ひ び割れ検出手法としての評価方法と，ひび割れとノイズへ の作用の比較評価を目的に、ひび割れ画素のみの識別率, およびノイズ画素の増加数を加えた 3 種類の值にて定量評 価を行った。画像全体での識別率は， $E_{T C}$ をひび割れが正し く認識された画素数， $E_{T B}$ を背景が正しく背景と認識された 画素数とし, 式(10)で計算される。但し，ひび割れの検出は, 㛜密な画素単位での位置精度よりも，ひび割れの規模を得 ることが重要であることから， $E_{T C}$ をカウントする際に，真 のひび割れ画素から 8 近傍までを許容範囲とした。

$$
E_{T}=\frac{E_{T C}+E_{T B}}{W \cdot H} \cdot 100
$$

ひび割れのみの識別率は, 画像中のひび割れ画素数に対し て，実際に検出された割合にて求めた。また，ノイズ画素 数は, 背景をひび割れ候補画素として誤検出した画素数で ある。

表 1 に式(10)によって得られた評価值, 表 2 にひび割れの みの正識別率, 表 3 にノイズ画素数を, それぞれ手法ごと に示す。表 1 では，值の差が僅かであるが，これは元々従 来手法でも高い值が得られており, 対象画像では, ひび割

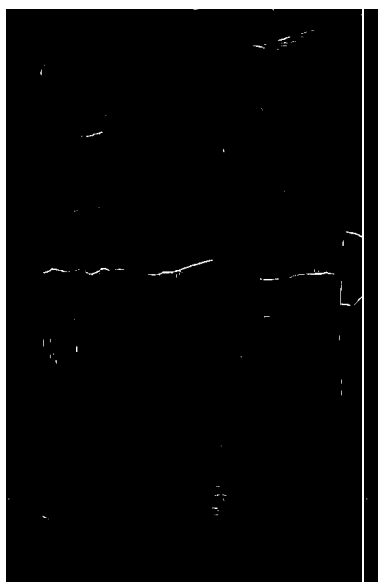

(a) Conventional method.

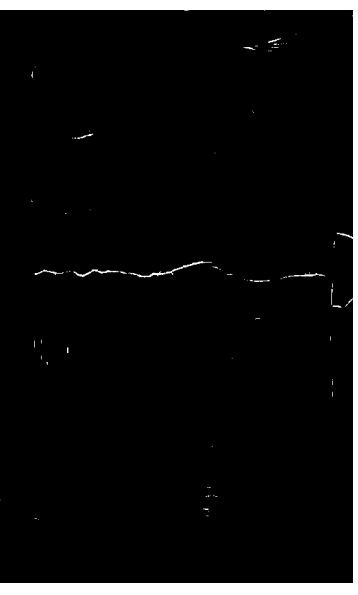

(b) Proposed method. 図 12 出力画像比較(Image2)
Fig. 12. Comparison of resultant images.(Image2)

表 1 識別率結果比較

Table 1. Comparison of total recognition rates.

\begin{tabular}{c|c|c}
\hline \hline Image Method & Conventional method & Proposed method \\
\hline Image1 & 99.64 & 99.68 \\
\hline Image2 & 99.63 & 99.69 \\
\hline
\end{tabular}

表 2 ひび割れ画素の正識別率結果比較

Table 2. Comparison of recognition rates for crack pixels.

\begin{tabular}{c|c|c}
\hline \hline Image Method & Conventional method & Proposed method \\
\hline Image1 & 65.93 & 84.91 \\
\hline Image2 & 50.83 & 78.67 \\
\hline
\end{tabular}

表 3 ノイズ画素数

Table 3. The numbers of noise pixels.

\begin{tabular}{c|c|c}
\hline \hline Image Method & Conventional method & Proposed method \\
\hline Image1 & 219 & 228 \\
\hline Image2 & 619 & 594 \\
\hline
\end{tabular}

表 4 反復処理回数と計算時間

Table 4. The numbers of repetition and processing time.

\begin{tabular}{c|c|c}
\hline \hline Image & The numbers of repetition & Processing time(s) \\
\hline Image1 & 17 & 277 \\
\hline Image2 & 12 & 203 \\
\hline
\end{tabular}

れよりも背景領域の画素数が大部分を占めるためである。 表 2 より，ひび割れそのものの識別率が Image1 は 19\%, Image 2 では $28 \%$ 向上している。表 3 でのノイズ画素数は, Image1 は 9 画素増加し, Image2 では 25 画素減少した。 
ノイズ画素の増減数が小さいことから，提案手法はノイズ 画素に対して，ほとんど強調作用を与えていないことが確 認できた。提案手法では, ひび割れの検出漏れを減少させ ることを目的としているため，ノイズ画素がほとんど増加 せず，かつ，ひび割れの正識別率が向上したことより，有 効性が確認された。

〈4·4〉処理回数と計算時間 表 4 にひび割れ候補画素 検出に実行された反復処理回数と, 合計処理時間を示す。 処理時間は，1回あたり 17 秒程度であり，10 回以上の反復 処理が必要であったことから, それぞれ 3 分〜 4 分以上の計 算時間となった。実際にひび割れ検出のシステムとして運 用する場合，およそ 2000 枚の画像を扱う必要があり，1台 の PC では，1 日以内に処理を完結することは困難である。 計算時間の内訳は，ひび割れ候補画素検出で用いるフィル 夕処理の時間が 9 割以上を占めていた。反復処理過程では, ある反復段階と, その次の段階では, 入力画像の画素值の 大部分が変化しないことから, フィルタ処理を行う画素数 の大幅な削減が可能であり, 高速化が可能と考えられる。

\section{5. まとめ}

下水道内面画像について, ノイズとなる背景構造物に対 して，ひび割れが広い領域で方向性を持つことを利用し， ひび割れ候補画素の検出精度を向上させる手法を提案し た。ひび割れ候補画素検出処理を反復的に行い, 各段階の 処理結果画像に対して, 方向性を用いた平滑化処理を施し, 検出の妨げとなるノイズ画素を除去することで，最終段階 での出力画像では, ひび割れに対する正識別率が向上した ことを確認した。提案手法では，ひび割れの方向性に着目 しているが，ノイズとなる構造物が，ひび割れの周辺に位 置する場合に，ノイズ画素として誤検出される傾向が見ら れた。今後は方向性以外のパラメータについても検討し, ひび割れとノイズを更に適切に識別することが課題であ る。

(平成 18 年 5 月 22 日受付)

\section{文献}

(1) T. Yasuda, S. Taniguchi, S. Kamewada, and G. Okano : "Development of a crack evaluation system for superannuated tunnels.", Journal of Construction Management and Engineering, Vol.VI, No.435/VI-15, pp.139-144 (1991) (in Japanese)

安田 亨・谷口親平・亀和田俊一・岡野吾一:「老朽トンネルにおけ るクラック診断システムの開発」, 土木学会論文集 VI, 435/VI-15, pp.139-144 (1991)
(2) R. Kuroki and H. Yoshikawa : "Crack Diagnosis Expert System by Introducing Fuzzy Measure", Proceedings of Annual Conference of the Japan Society of Civil Engineers, Vol.52, pp.248-249 (1997) (in Japanese) 黒木礼則・吉川弘道: 「ファジィ測度を用いたひび割れ診断エキスパ 一トシステムの構築」, 土木学会年次学術講演会講演概要集共通セッ ション, Vol.52, pp.248-249 (1997)

(3) K. Terada and N. Hatami : "An Automated Crack Analysis Sytem", Journal of the Japan Society of Civil Engineers, Vol.83, No.3, pp.25-26 (1998) (in Japanese) 寺田啓治・畠見尚彦:「自動ひび割れ解析システム」, 土木学会誌, 83, 3, pp.25-26 (1998)

（4）脇川武美:「下水道管渠内面展開図化システムの開発」, 第 35 回下水 道研究発表会講演集, pp.312-314 (1998)

(5) T. Hatada, K. Goto, F. Saitoh, T. Oosaka, S. Numao, and N. Harimoto : "Crack Pixels Detection from Inner Side of Drain by Using Variable-sized Directional Filter", IEEJ Trans. EIS, Vol.126-C, No.6, pp.744-751 (2006-6) (in Japanese) 幡田敏行・後藤邦博・斉藤文彦・大坂昂資・沼尾信二・張本紀行 : 「方 向サイズ可変フィルタを用いた下水道内面ひび割れ候補画素の検 出」, 電学論 $(\mathrm{C}), 126,6, \mathrm{pp} .744-751$ (2006-6)

(6) K. Kido, J. Taguchi, and K. Sano : "Improvements of MRI Image Quality Using Directional Adaptive Filter", IEICE Trans. D-II, Vol.J79-D2, No.8, pp.1347-1353(1996-8) (in Japanese) 木戸邦彦・田口順一・佐野耕一:「方向依存型フィルタを用いた MRI 画像の画質改善」, 信学論 D-II, J79-D2, 8, pp.1347-1353 (1996-8)

(7) I. E. Abdou and W. K. Pratt : "Quantitative Design and Evaluation of Enhancement/Thresholding Edge Detectors", Proc. of the IEEE, Vol.67, No.5, pp.753-763 (1979)

(8) L. Kitchen and A. Rosenfeld : "Edge Evaluation Using Local Edge Coherence", IEEE Trans. on SMC, Vol.11, No.9, pp.597-605, (1981)

(9) F. Saitoh : "Curve Extraction Using Voting Process Based on Proximity and Continuity between Points", Vol.120-C, No.8/9, pp.1257-1264 (2000) (in Japanese) 斉藤文彦:「点間の近接と連続性評価に基づく投票処理による主観的 曲線の検出」, 電学論 $(C), 120,8 / 9$, pp.1257-1264 (2000)

（10）南敏・中村 納：「画像工学(増補)」, p.117, コロナ社 (1989)

幡 田 敏 行 (非会員) 2005 年 3 月岐阜大学卒業。現在,

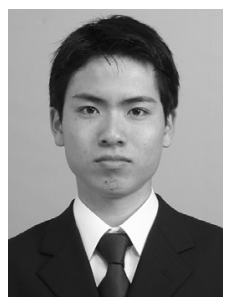
同大学工学研究科博士前期課程在学中。画像処 理の応用技術に関する研究に従事。

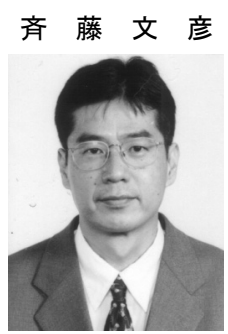

（正員） 1981 年慶大·工・数理卒。日本 $\operatorname{IBM}($ 株) 等を経て, 現在, 岐阜大学工学部応用情報学科 教授。博士 (情報科学、工学)。マシンビジョ ン, 視覚情報処理の研究に従事。精密工学会, 電子情報通信学会，画像電子学会等会員。 